\title{
Diffusion and Innovation Theory: Past, Present, and Future Contributions to Academia and Practice
}

\author{
Richard Baskerville $^{1}$, Deborah Bunker ${ }^{2}$, Johan Olaisen $^{3}$, Jan Pries-Heje ${ }^{4}$, \\ Tor. J. Larsen, ${ }^{3, *}$, and E. Burton Swanson ${ }^{5}$ \\ ${ }^{1}$ Georgia State University, Atlanta, USA \\ Baskervilledacm.org \\ ${ }^{2}$ The University of Sydney Business School, Sydney, Australia \\ Deborah. Bunker@sydney.edu.au \\ ${ }^{3}$ BI Norwegian Business School, Oslo, Norway \\ \{Johan. Olaisen, Tor.J. Larsen\}@bi.no \\ ${ }^{4}$ Roskilde University, Roskilde, Denmark \\ Janpharuc. dk \\ ${ }^{5}$ UCLA Anderson School of Management, Los Angeles, USA \\ Burt. Swansoneanderson.ucla.edu
}

Keywords: Diffusion theory, Innovation theory, Theory development, Value, Academia, Practice.

\section{Background}

The field of information systems (IS) has throughout its history experienced extensive changes in technology, research, and education. These renewals will continue into the foreseeable future [10]. It is recognized that IS is a key force in the ongoing societal and organizational renewal and change $[2,8,14]$. For example, in the US business sector, IS continues yearly to consume about $30 \%$ of total investments made [5]. Recent research document that IS supports the creation of business value, with particular emphasis on an organization's innovation and change capabilities [1,3]. Traditionally, research in IS has been interdisciplinary in nature - since it draws on innovation theory, models of value creation, actors' roles and behaviors, the creation and running of task oriented groups, and how these relate to organizational structures and mechanisms [24]. Throughout its history the question of benefits from investing in IS has been lively discussed.

It is emphatically true that IS software creators, consultancies, and organizations taking IS into use have done what they deem is necessary to carry through IS-related development, implementation, and usage processes. As we know, these actors have developed methods, techniques, procedures for securing competence, and tools for supporting the creation and maintenance of the IS portfolio. Although the path of IS development and use has been winding and full of potholes, it is equally apt to

\footnotetext{
*Panel Moderator.

B. Bergvall-Kåreborn and P.A. Nielsen (Eds.): TDIT 2014, IFIP AICT 429, pp. 295-300, 2014.

(C) IFIP International Federation for Information Processing 2014
} 
observe that despite of setbacks IS has over its decades of existence consistently enjoyed a staggering level of success.

Within the umbrella of innovation and change, what have been the contributions of academia? Indeed, Silicon Valley is a success story. Yet, in theoretical terms, what are the contributions in theory that have enjoyed wide use among software creators and user organizations?

IFIP WG8.6 was in 1993 created to bring together researchers and practitioners with a particular interest in diffusion of technology issues. In the group's early days Rogers' [25] theory of diffusion of innovation played a major role, resulting in a series of conference contributions (see, e.g., [17, 19]). The introduction of Davis' Technology Acceptance Model [7] in 1989 over time virtually killed the interest in Rogers' diffusion theory. We can safely say that TAM has enjoyed wide and intense attention with hundreds of publications (see, e.g., [18, 30]). Yet, it is exceedingly difficult to find evidence of practical application of TAM, that is, that TAM one way or other has been concretely included in IS projects and that TAM has worked as a vehicle for practitioners in understanding aspects of IS use. Diffusion theory and TAM address phenomena on the individual level of analysis. Examples of contributions on the organizational level are the Capability Maturity Model [11] and Swanson's [26, 29] explorations of innovation theory. Yet, it is unclear whether these have resulted in further theory developments or have enjoyed wide use in practice. These questions are also raised about process oriented approaches, such as Soft Systems Thinking [6].

The panel is put together to address these and related issues. We ask, what have been major contributions within the umbrellas of diffusion and innovation theory related to IS since the mid 1990ies? Are these still alive, and if not, what would it take to re-invoke them? If what we in academia have addressed so far are dead ends, what other approaches to theory building should we cultivate, and what would those diffusion and innovation theories actually be? Who would benefit from our endeavors; practitioners or academicians?

\section{Position Statements}

\subsection{Baskerville: No Silver Canon-Ball - Dodging the Limits of Theory}

Each Diffusion and Innovation Theory allows us to explain different aspects of the events under inspection. For example, technology push-pull is an early, but well known theory, often used to explain how production and market forces affect innovation and diffusion. Each such theory is limited to its explanatory scope. When used strategically, such theories will only provide part of the strategy: the core aspect selected in hopes this chosen strategic core will drive the entire setting in the desired direction. These are high hopes given the complexity with which such events unfold. A strategy for diffusion and innovation creates something of a synthetic collision: a kind of engineered complex event that almost immediately exceeds theoretic control. Such a collision creates lots of interesting (and useful) noise, changing everything associated with the events: individuals, societies, cultures, organizations, the technology itself, and even its utility. Theories that successfully explain aspects of such events may prove unsuccessful in 
strategizing them simply because the scope of the resulting strategy is insufficient to deal with the range of the unfolding complexity.

\subsection{Bunker: Diffusion and Innovation Theory - Real or Just an Illusion?}

There have been many major contributions to diffusion and innovation theory since 1990. The IFIP WG8.6 has accepted papers on the aggregate contributions in this area since 2008. By way of example, Dwivedi, Levine, Williams, Singh, Wastell, and Bunker [9] reviewed the evolution IFIP WG8.6 since its inception in 1993, as a means of understanding the research themes and approaches that have occupied the group during this time. Most frequently researched topics have included 'organizational impact, technology transfer, diffusion, software engineering and adoption' whilst research approaches such as 'actor-network theory, diffusion of innovation, and institutional theory' have been the most utilized by researchers within the group.

The real crux of the argument is, however: is diffusion and innovation theory real and relevant or just an illusion?

The core of our work is alive to our academic colleagues. For example, we still see the influence of Fred Davis [7] and his work on the technology acceptance model (cited in 18.650 instances to date) especially in the formative work of many of our research students. We still fail, however, to effectively address the issue of usefulness of such ideas within society and business, and their relevance to our practitioner colleagues. The original mission of the WG8.6 was to address this very issue, by actively engaging with practitioners, but this problem transcends mere "engagement" to the need for a model of knowledge and systems co-creation and co-production. True diffusion, innovation and technology transfer must occur "on location" where theory makers and theory users can work though practical/practice based implications of diffusion and innovation theory and their relevance [4].

Within IFIP WG 8.6 we have completed some rigorous and relevant research. However, we need to do more to co-produce diffusion and innovation theory, frameworks and approaches with our practitioner colleagues, in order to overcome the illusory nature of what it is we do. This would mean that both academics and practitioners (ably supported with funding from government) would need to set a suitable and practical agenda that addresses such issues as: research themes of importance, colocation of academic and practitioner researchers, shared research language, agreed to methods of: representation, categorization and research; and workable IP models.

If we were able to effectively tackle this issue then both practitioners and academicians would be able to harness mutual and complimenting strengths to produce useful, relevant, rigorous and robust theory, frameworks and approaches as well as a reinforcing "learning loops" to ensure continuous improvement of both theoretical and practical outcomes of our work.

\subsection{Olaisen: Value Creation in a Philosophy of Science Perspective - Subjective Pluralism or Objective Trivialism}

My position is an integrated view of IS. For an organization IS will include people, processes, structures, technology/tools and the context. The context includes both the 
internal and external parts of an organization. This means that the global customers, partners and networks are included. IS will then be handling both global efficiency and effectiveness -- likewise standardization and specialization of production and services. IS are then handling an increasing degree of internal and external complexity. IS logistics are then a primary requirement for any kind of value creation. Any business innovation and entrepreneurship capabilities include IS. To work smarter and greener is an IS issue. The edge of the research and development for this reality in any respect is today found in the business world and not in the academic world. Why? The academic IS world produce trivial empirical research without any relevance than for the academic world itself. IS are not anymore an important part of the business schools curriculum. The academic world do not participate in the IS business world or vice versa. The only way to do research upon IS will be a in a holistic perspective where the value creation is understood as a part of the whole business reality. This requires research paradigms as action research and clarified subjectivity research describing the past and present predicting the future. The empirical IS research and theoretical models of IS are outdated and irrelevant. We need a rebirth of IS research based upon clarified subjectivity exploring the present and future. We need subjective sensitizing research concepts not definitive objective empirical concepts. That might give us a brave new academic IS world!

\subsection{Pries-Heje: A Broad Unifying Perspective on Diffusion and Adoption}

Many theories look at a small and detailed part of diffusion and adoption. However, organizational change requires much more than a "view through a straw". I argue that we need to look broadly and across theories to find what is needed to design effective diffusion and adoption. I present a first draft that starts out with the people involved in different roles $[21,32,33,34]$. Look at phases that change goes through $[15,16,20]$. Distinguish between forced and voluntary change [25]. Aim at planning for change with end in mind [13]. And finally - based on contingencies of the situation recommend an organizational change strategy $[12,22]$.

\subsection{Swanson: Meeting the Institutional Challenge}

While much research on the diffusion of IT innovation has focused on the uptake of technology by first, individual users, and second, individual organizations, rather little has focused on the technologies themselves and their institutional trajectories and histories. Considerable opportunities exist for impactful research at this broader level of analysis (see, e.g., [31,35]), though there are challenges in building a community committed to it. My own research [27, 28] has promoted the concept of the organizing vision as a way to understand certain IT innovation in an institutional context, and while others have built on this work, the cumulative effort has not yet opened a gate through which many are attracted to enter and join (for one call, see [23]). More widely, the IS academic community's engagement of its research subject matter at the institutional level remains rather weak, with the consequence that narrower findings are often presented out of historical context, curiously, as if they were somehow invariant with the passage of time and IT innovation itself. 


\section{References}

1. Aral, S., Brynjolfsson, E., Wu, L.: Three-way Complementarities: Performance Pay, Human Resource Analytics, and Information Technology. Management Science 58(5), 913-931 (2012)

2. Baskerville, R.L., Myers, M.D.: Information Systems as a Reference Discipline. MIS Quarterly 26(1), 1-14 (2002)

3. Brynjolfsson, E., McAfee, A.: Race Against the Machine: How the Digital Revolution is Accelerating Innovation, Driving Productivity and Irreversibly Transforming Employment and the Economy. Digital Frontier Press, Lexington (2011)

4. Bunker, D., Campbell, J.: A Perspectival Punctuated Action Approach to Policy Development in Information Technology and Systems. In: Proceedings of the 16th Australasian Conference on Information Systems, Sydney, Australia, November 29-December 2 (2005), http: //aisel.aisnet.org/

5. Centre for the Study of Living Standards (2012), http: / /www. csls . ca/ (last accessed on November 12, 2012)

6. Checkland, P., Holwell, S.: Information, Systems and Information Systems - Making Sense of the Field. John Wiley \& Sons, Chichester (1998)

7. Davis, F.D.: Perceived Usefulness, Perceived Ease of Use, and User Acceptance of Information Technology. MIS Quarterly 13(3), 319-340 (1989)

8. Davis, G.B.: Information Systems Conceptual Foundations: Looking Backward and Forward. In: Baskerville, R., Stage, J., DeGross, J.I. (eds.) Proceedings of the IFIP WG8.2 Conference on The Social and Organizational Perspective on Research and Practice in Information Technology, Aalborg, Denmark, June 9-11, pp. 61-82. Kluwer Academic Publishers, Boston (2000)

9. Dwivedi, Y.K., Levine, L., Williams, M.D., Singh, M., Wastell, D.G., Bunker, D.: Toward an Understanding of the Evolution of IFIP WG 8.6 Research. In: Pries-Heje, J., Venable, J., Bunker, D., Russo, N.L., DeGross, J.I. (eds.) IFIP WG. IFIP AICT, vol. 318, pp. 225-242. Springer, Heidelberg (2010)

10. Galliers, R.D., Currie, W.L.: The Oxford Handbook of Management Information Systems: Critical Perspectives and New Directions. Oxford University Press, Oxford (2011)

11. Herbsleb, J., Zubrow, D., Goldenson, D., Hayes, W., Paulk, M.: Software Quality and the Capability Maturity Model. Communications of the ACM 40(6), 30-40 (1997)

12. Huy, Q.N.: Time, temporal capability, and planned change. Academy of Management Review 26(4), 601-623 (2001)

13. Jackson, P.Z., McKergow, M.: The Solutions Focus. Nicholas Brealey Publishing, London (2007)

14. Kebede, G.: Knowledge management: An Information Science Perspective. International Journal of Information Management 30, 416-424 (2010)

15. Kotter, J.P.: Leading Change: Why Transformation Efforts Fail. Harvard Business Review 73(2), 59-67 (1995)

16. Kotter, J.P.: Accelerate! Harvard Business Review 90(11), 43-58 (2012)

17. Larsen, T.J.: The Phenomenon of Diffusion: Red Herrings and Future Promise. In: Ardis, A.M., Marcolin, B.L. (eds.) Proceedings of the IFIP WG8.6 Conference on Diffusing Software Product and Process Innovations, Banff, Canada, April 7-10, pp. 35-50. Kluwer Academic Publishers, Boston (2001)

18. Legris, P., Ingham, J., Collerette, P.: Why do People Use Information Technology? A Critical Review of the Technology Acceptance Model. Information \& Management 40(3), 191-204 (2003) 
19. Lyytinen, K., Damsgaard, J.: What's Wrong with the Diffusion of Innovation Theory? In: Ardis, A.M., Marcolin, B.L. (eds.) Proceedings of the IFIP WG8.6 Conference on Diffusing Software Product and Process Innovations, Banff, Canada, April 7-10, pp. 173-190. Kluwer Academic Publishers, Boston (2001)

20. Moore, G.A.: Inside the Tornado. Harper Business (1995)

21. Pries-Heje, J.: Role Model for the Organisational IT Diffusion Process. In: Damsgaard, J., Henriksen, H.Z. (eds.) Networked Information Technologies: Diffusion and Adoption, pp. 115-129. Kluwer Academic Publishers (2003)

22. Pries-Heje, J., Baskerville, R.: The Design Theory Nexus. MIS Quarterly, Special Issue on Design Science Research 32(4), 731-755 (2001)

23. Ramiller, N.C., Swanson, E.B., Wang, P.: Research directions in information systems: Toward an institutional ecology. Journal of the AIS 9(1), 1-22 (2008)

24. Roberts, N., Galluch, P.S., Dinger, M., Grover, V.: Absorptive Capacity and Information Systems Research: Review, Synthesis, and Directions for Future Research. MIS Quarterly 36(2), 625-648 (2012)

25. Rogers, E.M.: Diffusion of Innovations, 5th edn. Free Press, New York (2003)

26. Swanson, E.B.: Information Systems Innovation among Organizations. Management Science 40(9), 1069-1092 (1994)

27. Swanson, E.B.: Illuminating Organizing Vision Careers through Case Studies. In: Proceedings of the Americas Conference on Information Systems, Chicago, IL (2013)

28. Swanson, E.B., Ramiller, N.C.: The Organizing Vision in Information Systems Innovation. Organization Science 8(5), 458-474 (1997)

29. Swanson, E.B., Ramiller, N.C.: Innovating Mindfully with Information Technology. MIS Quarterly 28(4), 553-583 (2004)

30. Venkatesh, V., Morris, M.G., Davis, G.B., Davis, F.D.: User Acceptance of Information Technology: Toward a Unified View. MIS Quarterly 27(3), 425-478 (2003)

31. Wang, P., Ramiller, N.C.: Community Learning in Information Technology Innovation. MIS Quarterly 33(4), 709-734 (2009)

32. Weinberg, G.M.: Quality Software Management. First-Order Measurement, vol. 2. Dorset House, New York (1993)

33. Weinberg, G.M.: Quality Software Management, Volume 3, Congruent Action. Dorse House, New York (1994)

34. Weinberg, G.M.: Quality Software Management. Anticipating Change, vol. 4. Dorset House, New York (1997)

35. Williams, R., Pollock, N.: Moving Beyond the Single Site Implementation Study: How (and why) We Should Study the Biography of Packaged Enterprise Solutions. Information Systems Research 23(4), 1-22 (2012) 